\title{
REPRODUCTIVE BIOLOGY AND CONDITION FACTOR OF THE CATFISH BAGRUS DOCMAK (FORSSKÅL) (PISCES: BAGRIDAE) IN LAKE CHAMO, ETHIOPIA
}

\author{
Hailu Anja 1, Elias Dadebo ${ }^{2}$ * and Seyoum Mengistou ${ }^{3}$ \\ ${ }^{1}$ Arba Minch College of Teachers` Education, PO Box 2052, Arba Minch, Ethiopia \\ ${ }^{2}$ Applied Biology Department, Hawassa University, PO Box 5, Hawassa, \\ Ethiopia. E-mail: edadebo@yahoo.com \\ ${ }^{3}$ Department of Biology, Faculty of Science, Addis Ababa University, PO Box 1176 \\ Addis Ababa, Ethiopia. E-mail: seyoumeng@gmail.com
}

\begin{abstract}
Some aspects of reproductive biology, length-weight relationship and condition factor of 534 (258 males and 276 females) Bagrus docmak (Forsskål) in Lake Chamo were studied from samples taken during February 1995 to February 1996. B. docmak had an extended breeding period from February to August, with peak spawning in May for both sexes, when $76.2 \%$ males and $78.3 \%$ females had ripe gonads. The main pulse in breeding activity occurred during the rainy months of April and May. The overall sex ratio (male: female) was 1:1.07 which did not deviate significantly from the hypothetical distribution of 1:1 $\left(x^{2}=0.61, \mathrm{p}>0.05\right)$. However, sex ratio was significantly different from 1:1 in the samples $>90 \mathrm{~cm}$ fork length (FL) $\left(x^{2}=10.71, \mathrm{p}<0.001\right)$. Size (FL) of first maturity was $62.0 \mathrm{~cm}$ for males and $69.0 \mathrm{~cm}$ for females. The mean number of eggs per female was 276,500. Ripe ovaries contained 990-2,100 eggs per gram of preserved wet weight with a mean number of 1,475. Fecundity was positively related to FL $\left(\mathrm{r}^{2}=0.75, \mathrm{p}<0.05\right)$, total weight $(\mathrm{TW})\left(\mathrm{r}^{2}=0.73, \mathrm{p}<0.05\right)$ and ovary weight $(\mathrm{OW})\left(\mathrm{r}^{2}=0.90, \mathrm{p}<0.05\right)$. Length-weight relationship of $B$. docmak is best expressed by the equation $\mathrm{TW}=$ 0.0054 FL $^{3.24}$. Monthly Clark's condition factor (mean $+/-\mathrm{SE}$ ) ranged from $0.426 \pm 0.011$ to $0.489 \pm 0.014$ for males and from $0.449 \pm 0.010$ to $0.489 \pm 0.012$ for females.
\end{abstract}

Key words/phrases: Breeding season, condition factor, fecundity, size at first maturity

\section{INTRODUCTION}

The bagrid catfishes are widely distributed in African and Asian freshwaters. About 100 species occur in African freshwaters (Lowe-McConnell, 1987) widely distributed in the basins of Gambia, the Nile system, Chad, Niger, Senegal, the Volta and most of the East African rift lakes (Risch, 1986; Golubtsov et al., 1995). In Ethiopia, the catfish Bagrus docmak (Forskål) occurs in the most southern rift valley lakes: Abaya and Chamo (Shibru Tedla, 1973), in Segen River (Risch, 1986) and in the Nile system (Golubstov et al., 1995). B. docmak is one of the commercially important fish species in Ethiopia. It is highly regarded by local people as food fish because it has few intramuscular bones. The same is true in other regions in Africa, for instance, around Lake Victoria (Benda, 1979; Marten, 1979).

Various workers have studied reproductive biology of $B$. docmak in some African water bodies (McKaye and Oliver, 1980; Rinne and Wanjala, 1983; Dadzie and Okach, 1989). The available information indicates that $B$. docmak moves to shallower water to spawn where it makes a nest on sandy bottom against rocks. Migration among other bagrid catfish populations from deeper areas to shallow inshore waters to spawn has also been reported by some authors (Corbet, 1961; Lock, 1975). According to Lowe-McConnell (1987) B. docmak females grow to a larger size than the males. The males stay on the breeding grounds for longer periods while guarding the eggs and the young (McKaye and Oliver, 1980).

The only study done so far on B. docmak in Lake Chamo is on its food and feeding habits (Hailu Anja and Seyoum Mengistou, 2001). B. docmak is one of the prey fish for the nile perch (Lates niloticus) in Lake Chamo. However, the latter has declined drastically in recent years due to overfishing (Elias Dadebo, 2001). The fishery of $B$. docmak became intensified after the overfishing, because fishermen switched to the next fish of choice - tilapia (Oreochromis niloticus), catfish (Clarias gariepinus) and B. docmak. At the same time, a very important food item, of B. domak, i.e., Labeo horie (Elias Dadebo, 1988; 2001) almost disappeared

\footnotetext{
* Author to whom all correspondence should be addressed.
} 
from Lake Chamo as a result of the destruction of its riverine breeding grounds and over-fishing. Moreover, the shallow shore areas which are the natural nursery grounds for juvenile $B$. docmak have experienced repeated toxic algal blooms as in 1978 and 2007 (Amha Belay and Wood, 1982; Personal Observation). Part of Lake Chamo is now monitored and protected by the African Parks Initiative in the overall effort to rehabilitate and conserve the Nech Sar National Park (African Parks, Personal Communication). Thus, the eventual success or failure of the $B$. docmak population in Lake Chamo depends on the interplay between these various factors and impacts. Knowledge of the condition factor and reproductive biology of the species is mandatory for considering priority options regarding the management and conservation of $B$. docmak in Lake Chamo.

This paper, therefore, sets to document some aspects of reproductive biology (breeding season, size at first maturity, fecundity), length-weight relationship and condition factor of $B$. docmak in the lake with the aim of providing the necessary scientific information for proper utilization and management of the stock.

\section{MATERIALS AND METHODS}

\section{Description of the study area}

Lake Chamo $\left(5^{\circ} 42^{\prime}-5^{\circ} 58^{\prime} \mathrm{N} ; 3^{\circ} 27^{\prime}-37^{\circ} 38^{\prime} \mathrm{E}\right)$ (Figure $1 \mathrm{a}$ and $1 \mathrm{~b}$ ) has a surface area of approximately $551 \mathrm{~km}^{2}$, a maximum depth of $16 \mathrm{~m}$ and lies at an altitude of 1,108 $\mathrm{m}$ (Amha Belay and Wood, 1982). The lake lies to the east of the Precambrian block of the Amaro Mountains within the less intensely faulted basin (Mohr, 1962). The surrounding region receives two rainy seasons per year, March-May (big rains) and SeptemberOctober (little rains). The mean annual rainfall of the area is about $1000 \mathrm{~mm}$ (Daniel Gamachu, 1977). During the past several decades, the water level of the lake has declined considerably and this has resulted in significant shrinkage of the lake's surface area. According to the more recent map of the lake region, its surface area has declined to about $335 \mathrm{~km}^{2}$ (Ethiopian Mapping Agency, 1988).

\section{Sampling}

This work was based on 534 (258 males and 276 females) individuals of $B$. docmak that were collected over a period of thirteen months between February 1995 and February 1996. We used stationary longlines to capture fish from three sites in the pelagic area of the lake (Fig. 1c). In addition, beach seine and small hook and line gear were used to obtain juvenile fish from the shallow littoral area. The commercial gillnet catch was also sampled from the landings. However, sampling methods other than the stationary longlines were usually not successful. Previous observation has shown that Synodontis schall (Bloch and Schneider) is the most favoured prey species of $B$. docmk (Hailu Anja and Seyoum Mengistou, 2001). Thus pieces of $S$. schall were used as bait. The hooks were usually set during the afternoon and lifted the following morning. Fork length (FL) of all fish was measured to the nearest centimetre immediately after capture. Total weight (TW) and Eviscerated Weight (EW) of fish under 1,000 g were weighed to the nearest gram whereas those between $1,000 \mathrm{~g}$ and 2,000 $\mathrm{g}$ were weighed to the nearest five grams. Larger specimens were weighed to the nearest $25 \mathrm{~g}$.

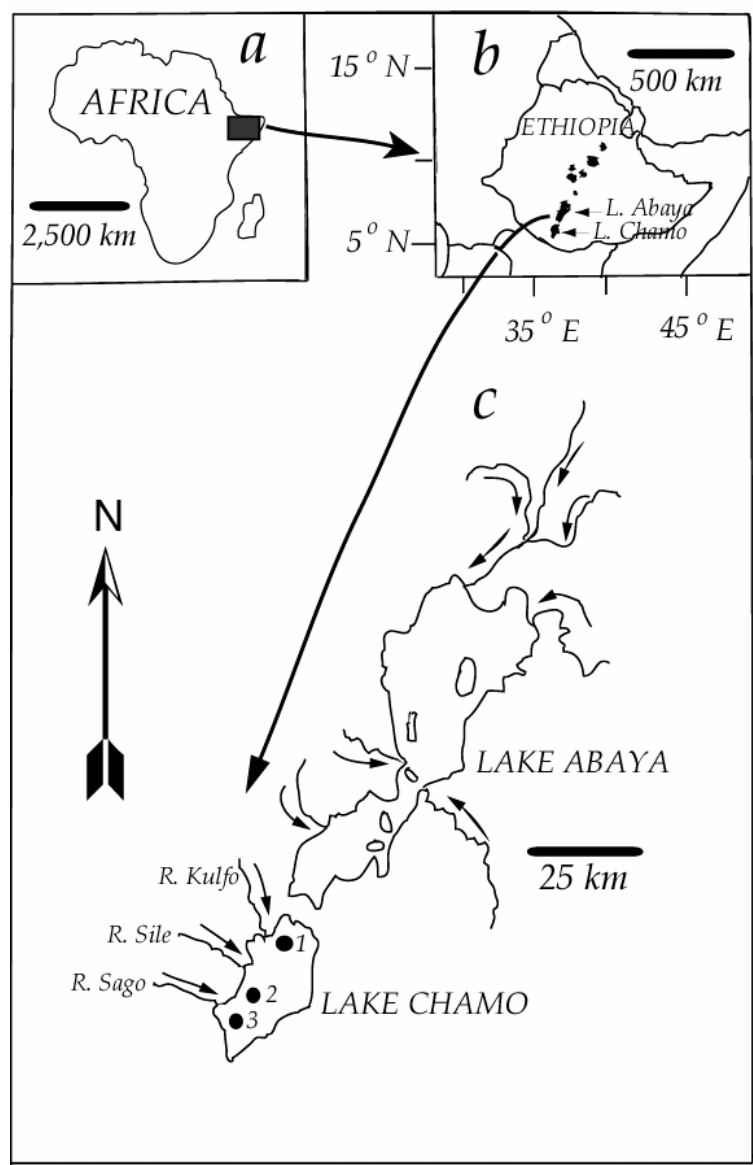

Fig. 1. Map of Africa with the relative position of East Africa highlighted (a), map of Ethiopia with the relative positions of the Rift Valley lakes indicated (b) and maps of Lakes Abaya and Chamo with the sampling stations in Lake Chamo indicated (c) (1- Deset, 2Bedena, and 3- Bole). 


\section{Breeding}

The sex and maturity stage of each fish were determined by visual examination of the gonads. A five-point maturity scale was used to determine maturity stages. The scale describes the development stages of gonads based on their sizes and the space they occupy in the body cavity (Holden and Raitt, 1974). Accordingly, fish are categorized as immature (I), recovering spent or developing virgin (II), ripening (III), ripe (IV) and spent $(\mathrm{V})$. Ripe ovaries were weighed to the nearest $0.1 \mathrm{~g}$, and preserved in Gilson's fluid for fecundity estimation. In order to assist penetration by the preservative, the ovaries were split longitudinally and turned inside out (Bagenal and Braum, 1978).

\section{Length at first maturity}

Average length at first maturity $\left(\mathrm{L}_{\mathrm{m} 50}\right)$ has been defined as the length at which $50 \%$ of the total number of individuals of a length group reaches maturity (Willoughby and Tweddle, 1978). This was determined from the relationship between the percentages of mature fish $(\mathrm{P})$ and length $(\mathrm{L})$, and from the coefficients ( $a$ and $\beta$ ) as described by the logistic function (Echeverria, 1987):

$$
\mathrm{P}=\mathrm{e}^{(a+\beta)} /\left(1+\mathrm{e}^{a+\beta L}\right)
$$

and the value of $\mathrm{L}_{\mathrm{m} 50}$ can be estimated from:

$$
L_{m 50}=-a / \beta
$$

The individuals of fish used in the estimation of $\mathrm{L}_{\mathrm{m} 50}$ were collected during the spawning season (i.e., February-August 1995). The proportion of mature fish for each $5-\mathrm{cm}$ length class was calculated for both males and females and $a$ and $\beta$ were estimated using Marquardt's (1963) algorithm for non-linear least squares regression.

\section{Fecundity}

Fecundity of each ripe fish was estimated by the gravimetric method (Snyder, 1983). Thus after weighing all the eggs per fish first, three subsamples of $1 \mathrm{~g}$ of eggs from various parts of the ovaries were counted. The average of the three counts was calculated as fecundity. This was then used to estimate the fecundity from total weight of all the eggs. The relationship between fecundity and some morphometric measurements [ $\mathrm{FL}$, TW and (OW, ovary weight)] were estimated using least squares regression. The diameter of ripe eggs of $B$. docmak ranged from $0.66 \mathrm{~mm}$ to $1.50 \mathrm{~mm}$. The mean egg diameter was $1.05 \mathrm{~mm}$.

\section{Length- weight relationship}

The relationship between FL in $\mathrm{cm}$ and TW in $\mathrm{g}$ was calculated using the following formula:

$$
\mathrm{TW}=\mathrm{aFL}^{\mathrm{b}} \ldots
$$

where $\mathrm{a}$ and $\mathrm{b}$ are parameters.

\section{Condition factor}

Clark's condition factor (K) was used to study seasonal and sex based variations in the well being of B. docmak. K was calculated using the following formula (Bagenal and Tesch, 1978):

$$
\mathrm{K}=\mathrm{EW} / \mathrm{FL}^{\mathrm{b}} \times 100
$$

where

$$
\begin{aligned}
& \mathrm{EW}=\text { Eviscerated Weight }, \text { and } \\
& \mathrm{FL}=\text { Fork Length }
\end{aligned}
$$

Seasonal and sex-based variations in the $\mathrm{K}$ values were statistically tested using ANOVA, and means were compared using Tukey's multiple comparison method (Zar, 1984).

\section{Breeding season}

The breeding season of the fish was determined from the percentages of fish with ripe gonads in monthly samples.. Since fish with ripe gonads could be found at any time of the year, breeding season was taken as the period when relatively higher frequencies of ripe fish were caught. Breeding data were also compared with rainfall and temperature data which were obtained from the Meteorological Services Agency, Addis Ababa.. A chi-square test was used to determine if sex ratios varied from 1:1 in the different size classes (Frank and Althoen, 1994).

\section{RESULTS}

\section{Sex ratio}

The total sex ratio of male: female was 1:1.07. The ratio was not significantly different from the hypothetical $1: 1(p>0.05)$. Sex ratio in all $10-\mathrm{cm}$ length classes was not significantly different from 1:1 ( $p>0.4$ ) except for fish $>90 \mathrm{~cm}$ FL where females were more numerous than males (Table 1). Females appeared to grow to a larger size than 
males, because $85.7 \%$ of fish $>90 \mathrm{~cm}$ FL were females (Table 1). The largest fish caught in the study were two females with FL of $99.1 \mathrm{~cm}$ and TW of 16,500 g., and FL of $98.4 \mathrm{~cm}$ and TW of $17,400 \mathrm{~g}$, respectively. On the other hand, the largest male caught was $91.5 \mathrm{~cm}$ FL and weighed 12,000 g.

Table 1. Number of males, females and the corresponding sex ratios in samples of $B$. docmak from Lake Chamo.

\begin{tabular}{lrrrl}
\hline FL & Males & Females & SR & Chi-square \\
\hline $30.0-39.9$ & 4 & 8 & $1: 2.00$ & 1.33 \\
$40.0-49.9$ & 17 & 20 & $1: 1.18$ & 0.24 \\
$50.0-59.9$ & 38 & 27 & $1: 0.71$ & 1.86 \\
$60.0-69.9$ & 65 & 55 & $1: 0.85$ & 0.83 \\
$70.0-79.9$ & 91 & 95 & $1: 1.04$ & 0.09 \\
$80.0-89.9$ & 40 & 53 & $1: 1.33$ & 1.82 \\
$>90.0$ & 3 & 18 & $1: 6.00$ & $10.71^{* * *}$ \\
& & & & \\
Total & 258 & 276 & $1: 1.07$ & 0.61 \\
\hline
\end{tabular}

Note: $\mathrm{SR}=$ Sex ratio (male: female), $\mathrm{FL}=$ Fork length in $\mathrm{cm}$ Samples were grouped in $10.0-\mathrm{cm}$ size classes. ${ }^{* *}$, very highly significant difference $(p<0.001)$.

\section{Breeding season}

Seasonal percentage frequency of ripe $B$. docmak is presented in Figure 2a. Fish with ripe gonads were caught throughout the year, however, the frequency was high during February to September for females and during February to August for males. Thus, intensive breeding occurred in those months, but the peak-breeding month was March for both sexes (Figure 2a). The proportion of males with ripe gonads was low during the months of September to December while the proportion of females with ripe gonads was relatively low during the months of October to December.

The proportion of breeding fish was generally high during the time of the year where the amount of precipitation was high (Figure 2b). Based on data averaged over 28 years (1972-1999) the rainy season of the area is biannual: February to May (heavy rains) and September and October (little rains) (Ethiopian Meteorological Services Agency, unpublished data). During the present study, the heavy rains occurred during April and May (Figure 2b). Mean monthly maximum air temperature decreased and mean monthly minimum air temperature increased during the rainy season (Figure $2 b$ ).
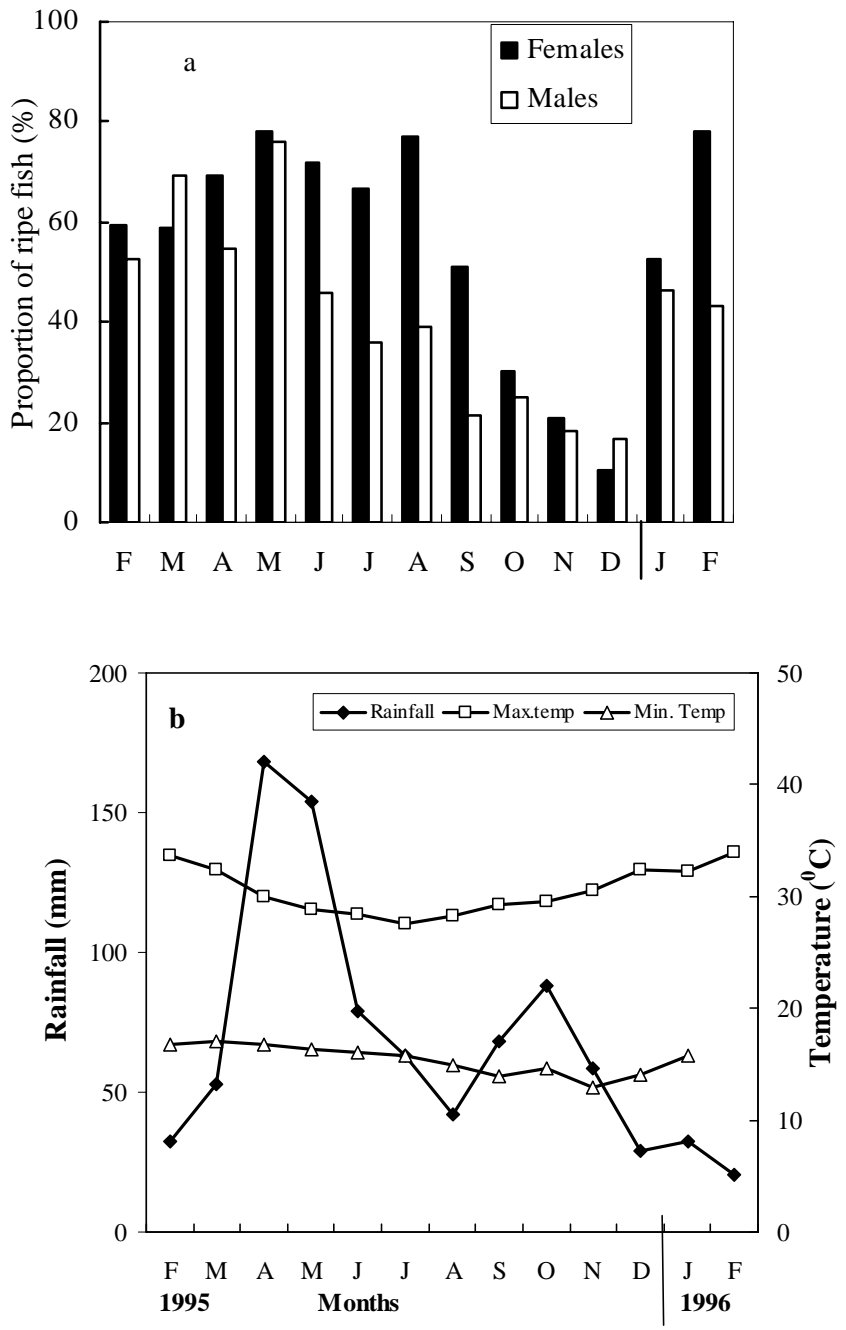

Fig. 2. Breeding season of $B$. docmak as indicated by the percentage of fish with ripe gonads (a), mean monthly air temperature (b) of Lake Chamo region.

\section{Length at first maturity}

The $\mathrm{Lm}_{50}$ was found to be $62.0 \mathrm{~cm}$ FL for males and $69.0 \mathrm{~cm}$ FL. for females The smallest mature male caught was $51.0 \mathrm{~cm}$ FL whereas the smallest mature female was $60.2 \mathrm{~cm}$ FL.

\section{Fecundity}

The number of eggs in ripe ovaries of $B$. docmak ranged from 94,500 to 615,500 with a mean of 276,500 eggs. The number of eggs per gram of ovary ranged from 990 to 2,100 with a mean of 1,470 .

The relationships between $\mathrm{F}$ and FL (Fig. 3a), F and TW (Fig. 3b) and F and OW (Fig. 3c) were all positive and statistically significant. The best-fit equations to the relationships, respectively, were: 


$$
\begin{aligned}
& \log F=3.395 \log F L-1.15,\left(r^{2}=0.73, p<0.05\right) \ldots \ldots . \\
& \log F=1.26+1.037 \log T W,\left(r^{2}=0.75, p<0.05\right) \ldots . . \\
& F=11,134 O W+2.39,\left(r^{2}=0.90, p<0.05\right) \ldots \ldots \ldots \ldots \ldots \ldots . .
\end{aligned}
$$
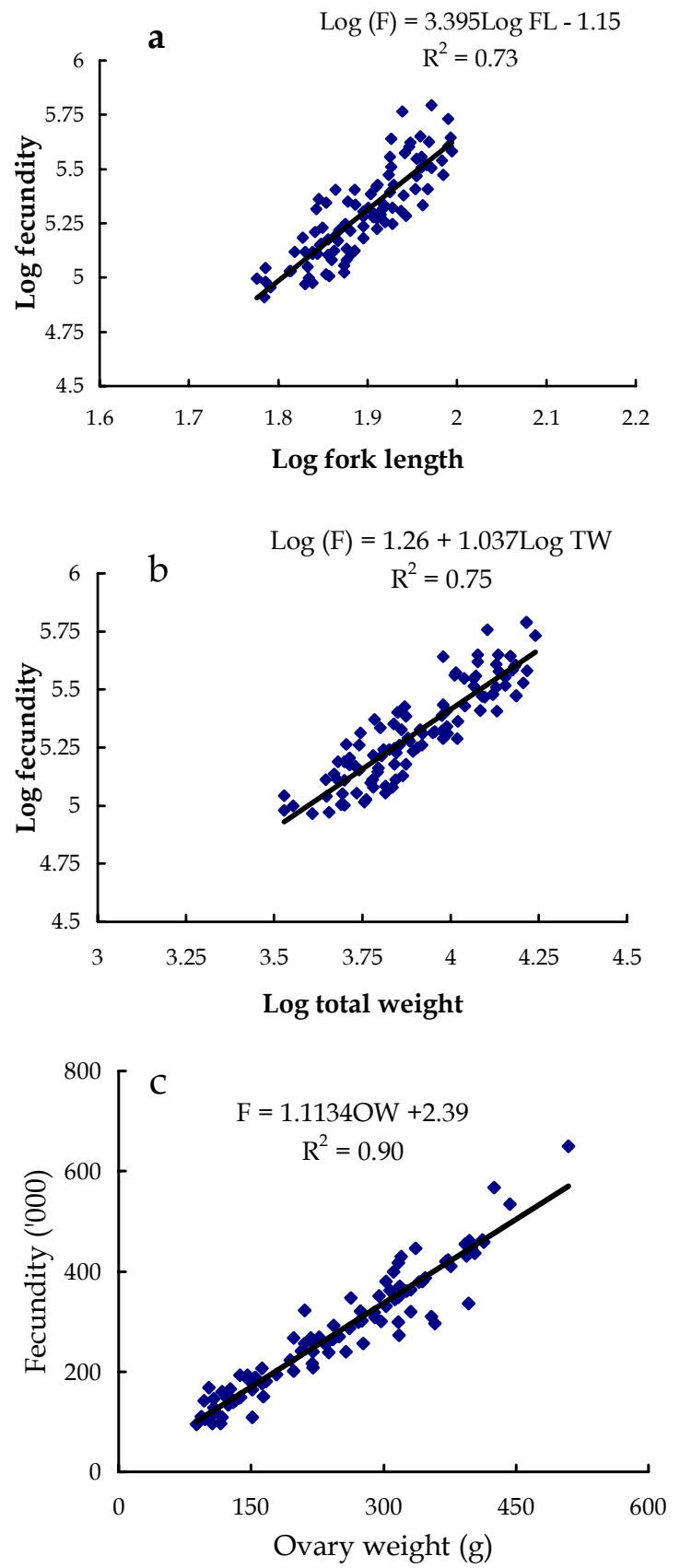

Fig. 3. The relationship between fecundity and total length (a), total weight (b) and ovary weight (c) of B. docmakfrom Lake Chamo.

The ovaries of the smallest mature female weighed $87.9 \mathrm{~g}$ ( $2.6 \%$ of the body weight $)$ and its fecundity was 95,500 eggs. The highest fecundity of 615,500 eggs was in a fish that was $94.0 \mathrm{~cm}$ FL and $16,300 \mathrm{~g}$ TW. Its ovaries weighed $510 \mathrm{~g}$ ( $3.1 \%$ of its body weight).

\section{Length-weight relationship}

Length-weight relationship was curvilinear and statistically significant $\left(\mathrm{r}^{2}=0.89, \mathrm{p}<0.05\right)$. The regression equation fitted to the data $(n=534)$ was as follows:

$\mathrm{TW}=0.0054 \times \mathrm{FL}^{3.24}$

\section{Condition factor}

Clark's condition factor (Mean \pm SE ) of B. docmak ranged from $0.436 \pm 0.011$ to $0.489 \pm 0.014$ for males, and from $0.449 \pm 0.011$ to $0.489 \pm 0.012$ for females. The smallest condition factor was recorded in February for males and in July for females. The largest condition factor was recorded in January for males and in February for females (Fig. 4). The $K$ values did not vary significantly (ANOVA, $F=4.77$, $p>0.05$ ) between sexes. ANOVA showed a significant variation in condition factor among different months $(\mathrm{F}=2.73, \mathrm{p}<0.01)$. The interaction term between month and sex was also insignificant suggesting a similar seasonal fluctuation pattern in conditions of both males and females (ANOVA, $\mathrm{F}=0.75, \mathrm{p}>0.05$ ). However, multiple comparison tests using Tukey's method could not detect variation in condition of the fish among the different months.

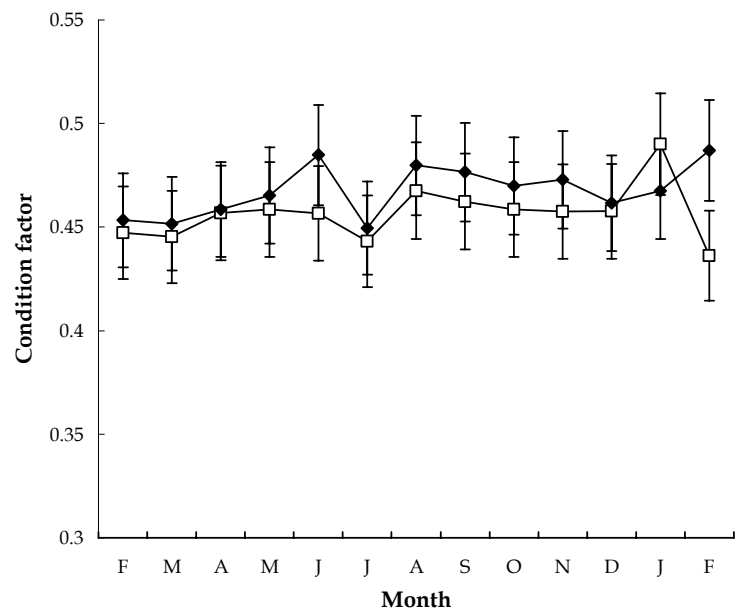

Fig. 4. Monthly average Clark's condition factor indices of $B$. docmak from Lake Chamo, (口- males, $\diamond$-females).

\section{DISCUSSION}

The overall sex ratio of $B$. docmak was not significantly different from 1:1 during the present study. Significantly more female than male fish were observed in the larger size classes $(>90 \mathrm{~cm}$ 
FL). This could be because of the difference in growth rate of the sexes where females attain larger sizes than males. Dadzie and Okach (1989) also reported a predominance of females in larger size classes of the same species in Lake Victoria.

B. docmak in Lake Chamo exhibited a long breeding season where intensive breeding activity occurred during the months of February to August. During the other months, even though considerable proportions of fish were found in breeding condition, their proportion was much lower than that in main breeding season. In Lake Awassa, a Rift Valley lake about $250 \mathrm{~km}$ north of Lake Chamo, Elias Dadebo (2000) reported that the catfish C. gariepinus has an extended breeding season from February to August. In Lake Victoria, B. docmak displayed a protracted spawning activity with at least half of the population in spawning condition occurring throughout the year (LoweMcConnell, 1987). Several environmental factors could be responsible for the high breeding activity of B. docmak in Lake Chamo during the months of February to August. The major rainy season of the area falls within this period. High rainfall and the subsequent rise in water level were implicated as the triggering factors for spawning of $B$. docmak in Lake Victoria (Rinne, 1975; Dadzie and Okach, 1989) and B. meridionalis (Gunther) in Lake Nyasa (Jackson et al., 1963). Dadzie and Okach (1989) also suggest that decline in water conductivity as a result of flooding and rise in water level could be spawning stimuli for $B$. docmak.

Temperature plays an important role in triggering reproduction in fish (Billard and Breton, 1978). (Maximum-minimum air temperature changes have been examined from data obtained from Ethiopian Meteorological Services Agency (1972-1999, unpublished data). In this study, the mean maximum air temperature decreased and the minimum air temperature increased during the rainy season (Fig. 2b). During the present study period, the average difference between maximum and minimum air temperature of the breeding season (February to August) was $13.4^{\circ} \mathrm{C}$. On the other hand, the average difference during the dry season (November to January) was $18.9^{\circ} \mathrm{C}$. During the rainy season, cooler day time temperatures and warmer night temperatures could possibly create favourable condition for spawning in this fish. This phenomenon has also been shown to have a possible effect on spawning activity of $C$. gariepinus in Lake Awassa (Elias Dadebo, 2000).

The sizes at $50 \%$ maturity of B. docmak $(62 \mathrm{~cm}$ for males and $69 \mathrm{~cm}$ for females) were much larger than those reported by Dadzie and Okach (1989) for the species in Lake Victoria $(23.2 \mathrm{~cm}$ for males and $33.2 \mathrm{~cm}$ for females). Size at maturity is negatively correlated to the degree of fishing mortality. As mortality increases, fish populations respond to the new circumstances by changing their life-history pattern in order to compensate for the losses imposed by fishing activity (Garrod and Horwood, 1984; Wootton, 1998). Such a large discrepancy in the size of first maturity in the two environments could be due to the difference in fisheries activity. For instance, in Lake George (Uganda) size at maturity of tilapia (O. niloticus) was lowered following years of intensive fishing activity (Gwahaba, 1973). Regrettably, no study is available that relates the size at first maturity of $B$. docmak to the degree of fishing activity in Lake Chamo.

Fecundity increased in proportion to 3.40 power of the length and 1.04 power of the weight (Fig. 3a, b). This is high when compared with the findings of Dadzie and Okach (1989). According to Dadzie and Okach (1989) fecundity of B. docmak in Lake Victoria increased in proportion to 1.45 power of the length and 0.74 power of the weight. In many tropical freshwater fish species, fecundity increases in proportion to 2.81-3.96 power of total length (Lowe-McConnell, 1975). Bagenal and Braum (1978) reported that the value of $b$ (slope of the fitted line) is about 3 when fecundity is related to the length and about 1 when it is related to weight. B. docmak in Lake Chamo conforms to this general pattern of fecundity and fish size relationship. There was much unexplained variance when fecundity was related to length, weight and ovary weight of $B$. docmak in Lake Chamo. This indicates that other factors are also involved in affecting fecundity, in addition to morphometric measurements of fish, such as availability of food and egg size (Bagenal and Braum, 1978).

The length-weight regression coefficient (3.24) was close to the cube of the length as found by Vakily (1989) for B. docmak in River Congo, Zaire. Entsua et al. (1995) working on B. bayad from the tributaries of the Volta River (Ghana) and Alimoso (1989) studying B. meridionalis in Lake Malawi have reported regression coefficients very close to the cube. In the present study the deviation of $b$ value from three indicates that $B$. docmak in Lake Chamo has allometric growth pattern where the fish becomes more round as it increases in length (Bagenal and Tesch, 1978).

Condition factor for both males and females remained relatively constant throughout most of the sampling period, except in July, where both 
sexes had lower condition factors. This suggests that the fat reserves are not seriously depleted during gonad development. In fact, condition of the fish slightly improved. Availability of food throughout the year and continuous feeding during the time of gonad maturation could be the probable reasons. Low values of $\mathrm{K}$ for both sexes in July could be due to the loss of energy after the release of gonad contents. Lowered condition of fish immediately after spawning has been well documented in other fish stocks (Jones, 1970; Lee, 1972; Wingfield and Grimm, 1977).

In conclusion, $B$. docmak conforms to the general pattern of breeding in tropical environment where relatively higher proportions of fish are in breeding condition during the rainy season. Inundation of the littoral region during floods, low conductivity of the water, cooler day temperatures and warmer night temperatures are all implicated as possible factors affecting reproductive activities of the fish. Experimental studies are needed to identify the relative importance of these factors as reproductive cues. In order to protect the breeding population of B. dacmak, fishing could be restricted to the shallow littoral areas during the peak spawning months of March to August. September to December could be an open fishing season to $B$. docmak in Lake Chamo, as relatively few fish are reproducing during this time of the year. Since females start reproduction at larger size than males, capture size of the stock should be determined taking into consideration the size at first maturity of females, which is $69 \mathrm{~cm} \mathrm{FL}$.

\section{ACKNOWLEDGEMENTS}

We thank Ato Banjaw Bagida for his assistance during the field work. We are also grateful to the Department of Biology, Addis Ababa University and Hawassa College of Agriculture, Debub University for providing laboratory facilities. The School of Graduate Studies, Addis Ababa University, provided logistic support for the field trips. The study was financed by SAREC (Swedish Agency for Research Cooperation with Developing Countries).

\section{REFERENCES}

1. Alimoso, S.B. (1989). Management of catfish (Bagrus meridionalis Gunther) in southern Lake Malawi. Fishbyte 7(2):10-12.

2. Amha Belay and Wood, R.B. (1982). Limnological aspects of an algal bloom on Lake Chamo in Gamo Goffa Administrative region of Ethiopia in 1978. SINET: Ethiop. J. Sci. 5:1-29.
3. Bagenal, T.B. and Braum, E. (1978). Eggs and early life history. In: Methods for Assessment of Fish Production in Freshwaters, pp. 165-201, (Bagenal, T., ed.) Blackwell Scientific Publications. London.

4. Bagenal, T.B. and Tesch, F.W. (1978). Age and growth. In: Methods for Assessment of Fish Production in Freshwaters pp. 101-136, (Bagenal, T., ed.) Blackwell Scientific Publications, London.

5. Benda, R.S. (1979). Analyses of catch rate data from 1968 to 1976 from nine landings in the Kenya waters of Lake Victoria. J. Fish Biol. 14:385-388.

6. Billard, R. and Breton, B. (1978). Rhythms of reproduction in teleost fish. In: Rhythmic Activities of Fishes, pp. 31-53, (Thorpe, J.E., eds) Academic Press, London.

7. Corbet, P.S. (1961). The food of non-cichlid fishes of Lake Victoria Basin, with remarks of lacustrine conditions. Proc. Zool. Soc. Lond. 136:1-101.

8. Dadzie, S. and Okach, J.O. (1989). The reproductive biology of a siluroid catfish, Bagrus docmak (Cypriniformes: Bagridae) in the Winam Gulf of Lake Victoria. J. Afr. Zool. 103:143-154.

9. Daniel Gamachu (1977). Aspects of Climate and Water Budget in Ethiopia. Addis Ababa University Press, Addis Ababa.

10. Echeverria, T.W. (1987). Thirty-four species of California rockfishes: maturity and seasonality of reproduction. U. S. Fish. Bull. 85:229-250.

11. Elias Dadebo (1988). Studies on the biology and commercial catch of Clarias gariepinus Peters (Pisces: Claridae) in Lake Awassa, Ethiopia. M.Sc. Thesis. Addis Ababa University, 73 pp.

12. Elias Dadebo (2000). Reproductive biology and feeding habits of the catfish Clarias gariepinus Burchell (Pisces: Clariidae) in Lake Awassa, Ethiopia. SINET: Ethiop. J. Sci. 23:231-246.

13. Elias Dadebo (2001). Reproduction biology and feeding habits of some fish species in Lake Chamo, Ethiopia. Ph.D. Thesis, Addis Ababa University, $105 \mathrm{pp}$.

14. Entsua-Mensah, M., Osei-Abunyewa, A. and Palomares, M.L.D. (1995). Length-weight relationships of fishes from the volta River, Ghana: Part 1. Analysis on pooled data sets. Naga, ICLARM Q. 18(1):36-38.

15. Ethiopian Mapping Agency (1988). Map of Lake Chamo and the surrounding area, Scale: 1:50,000. Addis Ababa.

16. Frank, H. and Althoen, S.C. (1994) Statistics. Concepts and Application. Cambridge University Press. Cambridge.

17. Garrod, D.J. and Horwood, J.W. (1984). Reproductive strategies and the response to exploitation. In: Fish Reproduction, pp. 367-384, (Potts, G.W. and Wootton, R.H., eds) Academic Press, London. 
18. Golubtsov, A.S., Darkov, A.A., Dgebuadze, Y.Y. and Mina, M.V. (1995). An Artificial Key to Fish Species of Gambella Region. Joint Ethio-Russian Biological Expedition. Artistic Printing, Addis Ababa.

19. Gwahaba, J.J. (1973). Effects of fishing on Tilapia nilotica populations of Lake George, Uganda, over the past 20 years. J. E. Afr. Wildlife. 11:317328.

20. Hailu Anja and Seyoum Mengistou (2001). Food and feeding habits of the catfish, Bagrus docmak (Forskal, 1775) (Pisces: Bagridae) in Lake Chamo, Ethiopia. SINET: Ethiop. J. Sci. 24(2):239-254.

21. Holden, M.J. and Raitt, D.F.S. (1974). Manual of fisheries science. Part 2. Methods of resource investigation and their application. FAO Fish. Tech. Pap.115.

22. Jackson, P.B.N., Illes, T.D., Harding, D. and Fryer, G. (1963). Report on the survey of the northern Lake Nyasa (1954-1955). Govt. Printers. Zomba, Nyasaland.

23. Jones, A. (1970). Some aspects of the biology of the turbot (Scophthalmus maximus L.) with special reference to feeding and growth in the juvenile stage. Unpubl. PhD. Thesis, University of East Anglia, U.K.

24. Lee, C.K.C. (1972). The biology and population dynamics of the common dab Limanda limanda (L.) in the North Sea. Unpubl. PhD Thesis, University of East Anglia, U.K.

25. Lock, J.M. (1975). Preliminary report of the biology of Lake Rudolf catfish, Bagrus bayad. Proc. Symp. Biol. Fish. Lake Rudolf, Molo. 25-29 May 1975.

26. Lowe-McConnell, R.M. (1975). Fish Communities in Tropical Freshwaters. Longmans, London.

27. Lowe-McConnell, R.M. (1987). Ecological Studies in Tropical Fish Communities. Cambridge University Press, Cambridge.

28. Marquardt, D.W. (1963). An algorithm for least squares estimation of nonlinear parameters. J. Soc. Indust. Appl. Mathem. 11:431-441.

29. Marten, G.G. (1979). Predator removal: effect on fisheries yield in Lake Victoria. Science, New York. 203:646-648.
30. McKaye, A.R. and Oliver, M.F. (1980). Geometry of a selfish school: defense of cichlid young by a bagrid catfish in Lake Malawi. Anim. Behav. 28:1287.

31. Mohr, P.A. (1962). The Ethiopian Rift System. Bull. Geophys. Obs. 3(1):33-62.

32. Rinne, J.N. (1975). Reproductive biology of some siluroid catfishes in Lake Victoria. EAFRO Ann. Rep. 1975. pp. 27-40.

33. Rinne, J.N. and Wanjala, B. (1983). Maturity, fecundity and breeding seasons of the major catfishes (Suborder: Siluroidea) in Lake Victoria, East Africa. J. Fish Biol. 23:357-363.

34. Risch, L.M. (1986). Bagridae. In: Checklist of the freshwater fishes of Africa (CLOFFA), pp. 2-35 (Daget, J., Gosse, J.-P. and Thys van den Audenaerde, D.F.E., eds) ISNB. Brussels. MRAC, Tervuren and ORSTOM, Paris. Vol. 12

35. Shibru Tedla (1973). Freshwater Fishes of Ethiopia. Haileselasse I University Press, Addis Ababa.

36. Snyder, D.E. (1983). Fish eggs and larvae. In: Fisheries Techniques, pp. 165-197, (Nielsen, L.A. and Johnson, D.L., eds) Southern Printing Company Inc. Blacksburg, Virginia.

37. Vakily, J.M. (1989). Les peches dans la partie zairoise du Lac Idi Amin: Analyse de la situation actuelle et potentiel de developpement. Rapport Technique des Peches au Zaire. Environnement et Consrvation de la Nature, et Commission des Communautes Europeennes, Kinshasa/Brussels. 48 p. And Appendix.

38. Willoughby, N.G. and Tweddle, D. (1978) The ecology of the catfish Clarias gariepinus and Clarias ngamensis in the Shire Valley, Malawi. J. Zool. Lond. 186:507-534.

39. Wingfield, J.C. and Grimm, A.S. (1977). Seasonal changes in plasma cortisol, testosterone and oestradiol-17 $\beta$ in the plaice, Pleuronectes platessa L. Gen. Comp. Endocrinol. 31:1-11.

40. Wootton, R.J. (1998). Ecology of Teleost Fishes, $2^{\text {nd }}$ ed. Kluwer Academic Publishers, London.

41. Zar, J.H. (1984). Biostatistical Analysis, 2nd ed., Prentice and Hall Inc., New Jersey. 